\title{
Non-Discrimination Principle In The Indonesian Legislation Concerning Children*
}

\author{
${ }^{1}$ Zendy W.A W. Prameswari \\ Faculty of Law, Airlangga University \\ Surabaya, Indonesia \\ zendy@fh.unair.ac.id
}

\author{
${ }^{2}$ Dwi Rahayu Kristianti \\ Faculty of Law, Airlangga University \\ Surabaya, Indonesia \\ dwi.rahayu@fh.unair.ac.id
}

\begin{abstract}
Children are a group that is vulnerable to be violated or neglected of their rights. They are particularly vulnerable to discrimination in most societies. Besides experiencing discrimination based on their age, they also face discrimination on other grounds such as their gender, disability, or sexual orientation, and sometimes due to a

including monitoring the implementation and reviewing the national law to ensure that all legislation, policy and practice is compatible with the non-discrimination principle contained in the CRC. This article also argues that both direct and indirect discriminaton occur in the implementation of the Indonesian national law.
\end{abstract} combination of various reasons. Based on the Article 2 of the CRC, all forms of exemption and discrimination against children are prohibited. Indonesia has ratified the CRC through Presidential Decree Number 36/1990. Additionally, the 1945 Constitution of the Republic of Indonesia guarantees that Every child shall have the right to survive, to grow and to develop and to be entitled the right to protection from violence and discrimination. Unfortunately, some of the Indonesian legislation which are expected to protect and ensure the fulfillment of children's rights are discriminatory. This article mainly discusses about two main issues. Firstly, it scrutinizes the principle of non-discrimination as one of the general principles in the CRC. Secondly, it discusses the discriminatory nature of legislation in Indonesia concerning children. This study finds that as one of the general principles in the CRC, non-discrimination principle imposes State Parties to prohibit any form of discrimination and take positive action to promote children's right to be free from any forms of discrimination. It is the State's obligation to protect children from discrimination entails various state's actions,
Keywords-component; Non-discrimination principle; discriminatory legislation; direct and indirect discrimination.

\section{INTRODUCTION}

The Convention on the Rights of the Child (the $\mathrm{CRC}$ ) is the first instrument of human rights law that contains comprehensive child rights. 1 Article 1 of the CRC defines that the child is every human being below the age of eighteen (18) years, except according to the law applicable to the child, majority is attained earlier. As a person under the age of eighteen, of course children can also enjoy all the human rights guaranteed in other legal instruments such as the International Covenant on Civil and Political Rights (the ICCPR) and the International Covenant on Economic, Social and Cultural Rights (the ICESCR). Article 24 of the ICCPR and article 10 of the ICESCR states that children are entitled to special protection measures they need as children. The CRC provides the details of such safeguards.

The CRC is a legal instrument to promote and protect the rights of children. The CRC is the first Convention which fully guarantees the protection of children's rights in the economic, social, cultural, civil and political fields. In addition, the CRC is also the first international 
legal instrument that explicitly recognizes children as social actors and active owners of their own rights. ${ }^{2}$ The CRC sets out standards of treatment, care and protection of all children. ${ }^{3}$ UNICEF declares that the CRC is privileged, among others due to the some matters which one of them that the CRC indicates that children's rights are human rights. Children's rights are not special rights, but rather the fundamental rights inherent to the human dignity of all people, including children. Children's rights can no longer be perceived as an option, as a question of favour or kindness to children or as an expression of charity. They generate obligations and responsibilities that we all must honour and respect. 4

Children are a group that is vulnerable to be violated or neglected of their rights. This is the result of systemic discrimination, directly or indirectly, against children. Children are particularly vulnerable to discrimination in most societies compared to adults because their dependence on adults and adults's reluctance to give children the more decision-making power as the part of their ability development to exercise their own decisions. Besides experiencing discrimination as a group (agebased discrimination), children also face discrimination on other grounds such as their gender, disability, or sexual orientation, and sometimes due to a combination of various reasons. The Committee on the Rights of the Child has so far determined 53 reasons for discrimination against children based on either their identity or the identity of their parents.5 All forms of discrimination against children are aggravated by basing on their age and vulnerability which means they have fewer opportunities for confronting discrimination because, for example, they do not have access to court and complaints mechanisms that are equivalent to adults. 6

Article 2 the CRC stipulates that States Parties shall respect and ensure the rights set forth in the present Convention to each child within their jurisdiction without discrimination of any kind, irrespective of the child's or his or her parent's or legal guardian's race, colour, sex, language, religion, political or other opinion, national, ethnic or social origin, property, disability, birth or other status. Additionally, it provides that States Parties shall take all appropriate measures to ensure that the child is protected against all forms of discrimination or punishment on the basis of the status, activities, expressed opinions, or beliefs of the child's parents, legal guardians, or family members. Article 28B paragraph (2) of the 1945 Constitution of the Republic of Indonesia guarantees that "Every child shall have the right to survive, to grow and to develop and to be entitled the right to protection from violence and discrimination". In Article 21 of Law Number 35 of 2014 on Amendment to Law Number 23 of 2002 on Child Protection (hereinafter referred to as Law No. 35 of 2014) also provides that "States, Governments and Local Governments are responsible and oblige for respecting the fulfillment of the Rights of the Child, regardless of ethnicity, religion, race, class, culture and language, legal status, birth order, and physical and / or mental conditions ". In addition, Indonesia has ratified the CRC through Presidential Decree Number 36 of 1990 on the ratification of the Convention on the Rights of the Child (hereinafter referred to as Presidential Decree No. 36/1990).

Article 28I Paragraph (4) of the 1945 Constitution of the Republic of Indonesia stipulates that the protection, advancement, upholding and fulfillment of human rights are the responsibility of the state, especially the government. Further Article 28I Paragraph (5) of the 1945 Constitution of the Republic of Indonesia guarantees that for the purpose of upholding and protecting human rights in accordance with the principle of a democratic and law-based state, the implementation of human rights shall be guaranteed, regulated and set forth in laws and regulations. Besides Law No. 35 of 2014, there are many other legislations which also related to children. Unfortunately, some of the legislation which are expected to protect and ensure the fulfillment of children's rights are discriminatory. For example, Law Number 1 of 1974 on Marriage (hereinafter referred to as Marriage Law) stipulates the legal age of marriage of females is 16 and males is 19.

Based on the background described above, this paper attempts to analyze two main issues. Firstly, it will scrutinize the principle of nondiscrimination as one of the general principles in 
the CRC. Secondly, it will discuss the discriminatory nature of legislation in Indonesia concerning children. This study employs the Doctrinal Research Methodology since this research involves the study of law 'in the book' and is concerned with the formulation of legal 'doctrines' through the analysis of legal rules. Furthermore, it analyses the legal frameworks and human rights dimension of child's rights.

\section{THE PRINCIPLE OF NON- DISCRIMINATION AS ONE OF THE GENERAL PRINCIPLES IN THE CRC}

The CRC has four general principles, they are the right to non-discrimination (Article 2), the best interests of the child (Article 3), the right to survival and development (Article 6), and the right to express opinions freely in matters affecting him/her and to have those views taken into consideration (Article 12). Based on those general principles, the State Party must provide for and regulate the protection of all children under its jurisdiction from any kind of exploitation or abuse. Actions done by the State Party must be guided by the rights to protection from discrimination, the child's best interests, survival and development, and to express a view and have it respected.7

Article 2 paragraph 1 of the CRC stipulates that States Parties shall respect and ensure the rights set forth in the present Convention to each child within their jurisdiction without discrimination of any kind, irrespective of the child's or his or her parent's or legal guardian's race, colour, sex, language, religion, political or other opinion, national, ethnic or social origin, property, disability, birth or other status. In addition, Article 2 paragraph 2 of the CRC provides that States Parties shall take all appropriate measures to ensure that the child is protected against all forms of discrimination or punishment on the basis of the status, activities, expressed opinions, or beliefs of the child's parents, legal guardians, or family members.

Article 2 of the CRC aims to ensure the prohibition of all forms of exemption and discrimination. The article also applies as one of the general principles in the CRC which affirms that all children are recognized in their rights without discrimination on any grounds. 8 Article 2 of the CRC and its interpretation by the Committee on the Rights of the Child affirm that the state's obligation to avoid discrimination is an active obligation, requiring other aspects of implementation, a range of measures that include review, strategic planning, legislation, monitoring, awareness raising, education and information campaign, and evaluation of measures taken to reduce disparities.9

Non-discrimination is a fundamental principle in human rights law. It serves as the operational principle in key instruments of general human rights law.10 UDHR provides the provisions of non-discrimination in articles 2 and 7 . In the next development, there are many human rights instruments have guaranteed the non-discrimination principle to ensure de facto equality of particular individuals and groups of people. Each of these instruments focuses comprehensively on the elimination of discrimination on a certain ground. Besides the CRC, The most important international legal instruments against discrimination and inequality are the International Convention on the Elimination of All Forms of Racial Discrimination (CERD), the Convention on the Elimination of All Forms of Discrimination against Women (CEDAW).11 Another important instrument against discrimination is the recent Convention on the Rights of Persons with Disabilities (CRPD). Those international human rights law instruments essentially have a two-fold aim, which are guarantees the nondiscrimination and equal rights of particular individuals and groups, as well as special measures to ensure de facto equality (affirmative action). 12

The CRC does not provide the definition of term "discrimination". However, the terminology used in the Article 2 is the same as that of non-discriminatory provisions in other human rights law instruments. The Human Rights Committee, in its 1989 General Comment, emphasizes that "non-discrimination, together with equality before the law and equal protection of the law without any discrimination, constitute a basic and general principle relating to the protection of human rights". The Human Rights Committee notes that "the term 'discrimination' as used in the Covenant should 
be understood to imply any distinction, exclusion, restriction or preference which is based on any ground such as race, colour, sex, language, religion, political or other opinion, national or social origin, property, birth or other status, and which has the purpose or effect of nullifying or impairing the recognition, enjoyment or exercise by all persons, on an equal footing, of all rights and freedoms".13

The Committee on the Rights of the Child has not issued a General Comment to interpret Article 2 of the CRC. However, the issue of discrimination has evolved in other General Comments in relation to the theme of the subject.14 In its first general comment, issued in 2001, the Committee stated, however, that 'discrimination on the basis of any of the grounds listed in article 2 of the Convention, whether it is overt or hidden, offends the human dignity of the child and is capable of undermining or even destroying the capacity of the child to benefit from educational opportunities."15

In its General Comment No. 5 regarding the General measures of implementation for the Convention on the Rights of the Child (Article 4, 42 and 44 para. 6), the Committee notes that in its relation with Article 2, "This nondiscrimination obligation requires States actively to identify individual children and groups of children the recognition and realization of whose rights may demand special measures. For example, the Committee highlights, in particular, the need for data collection to be disaggregated to enable discrimination or potential discrimination to be identified. Addressing discrimination may require changes in legislation, administration and resource allocation, as well as educational measures to change attitudes. It should be emphasized that the application of the nondiscrimination principle of equal access to rights does not mean identical treatment."16

Additionally, In its General Comment No. 7 on the Implementing Child Rights in Early Childhood, the Committee on the Rights of the Child urges States Parties to identify the implications of the principle of nondiscrimination to realize the rights of early childhood. The Committee argues that based on
Article 2, young children in general must not be discriminated against on any grounds, for example where laws fail to offer equal protection against violence for all children, including young children. Young children are especially at risk of discrimination because they are relatively powerless and depend on others for the realization of their rights. The Comiittee also emphaziss that particular groups of young children must not be discriminated against. Discrimination may take the form of reduced levels of nutrition; inadequate care and attention; restricted opportunities for play, learning and education; or inhibition of free expression of feelings and views. Discrimination may also be expressed through harsh treatment and unreasonable expectations, which may be exploitative or abusive"17

The HRC goes on to emphasize that the "enjoyment of rights and freedoms on an equal footing, however, does not mean identical treatment in every instance". The principle of equality sometimes requires States Parties "to take affirmative action in order to diminish or eliminate conditions which cause or help to perpetuate discrimination prohibited by the Covenant." And finally, it states that "not every differentiation of treatment will constitute discrimination, if the criteria for such differentiation are reasonable and objective and if the aim is to achieve a purpose which is legitimate under the Covenant". 18

The aim of the CRC is that children are born with fundamental freedoms and the inherent rights of all human beings and should not be discriminated against because they are children. Non-discrimination is one of the guiding principles of the CRC. It should implies that all rights apply to all children without exception and that the state has an obligation to put into place the means to ensure children are protected from any form of discrimination and to take positive action to promote their rights free of discrimination. In practice this requires a range of measures that include review, strategic planning, legislation, monitoring, awarenessraising, education and information campaigns, and evaluation of measures taken to reduce disparities. 19 


\section{THE DISCRIMINATORY NATURE OF LEGISLATION IN INDONESIA CONCERNING CHILDREN}

A. Review on the Non-Discrimination Principles in the Legislation

Under Article 4 of the CRC, States Parties shall take the necessary legislative, administrative and other measures necessary for the exercise of the rights recognized in the CRC. In General Comment No. 5 concerning the General measures of implementation for the CRC (Article 4, 42 and 44 para. 6) issued by the Committee on the Rights of the Child in 2003, the Human Rights Committee stated that the State party should ensure that all arrangements in national law are fully consistent with the CRC. It also emphasizes that the general principles and provisions of the CRC can be applied directly.20

The Committee on the Rights of the Child emphasizes the importance of national laws reflecting the general principles in the CRC (Articles 2, 3, 6 and 12). Equally important are the laws that sectorally regulate the child (eg education, health, etc.) reflect the consistent principles and standards of the CRC.21

In Article 41 of the CRC, the state should be more conducive to the realization of the rights of the child. The Committee on the Rights of the Child has also emphasized the need for States to review their constitutions and all existing laws to ensure that the provisions of the Constitution and the law do not contain discriminatory provisions. 22

In the 3rd and 4th Periodic Report, Indonesia said that in recent developments Indonesia has established several laws relating to the protection of children such as:

(a) Law No. 13 of 2003 on Manpower 23;

(b) Law No. 20 of 2003 National Education System24;

(c) Law No. 23 of 2004 on the Elimination of Domestic Violence25;

(d) Law No. 11 of 2005 on the Ratification of the International Covenant on Economic, Social and Cultural Rights; (e) Law No. 12 of 2005 on the Ratification of the International Covenant on Civil and Political Rights;

(f) Law No. 12 of 2006 on the Citizenship of the Republic of Indonesia 26

(g) Law No. 23 of 2006 on Population Administration 27

(h) Law No. 17 of 2007 on the Long Term Development Plan of the Year 2005-2025;

(i) Law No. 21 of 2007 on the Eradication of Trafficking in Persons 28

(j) Law No. 24 of 2007 on Disaster Management 29

(k) Indonesia has signed the CRPD.

In addition, Indonesia also submitted to have ratified the CRC through a Presidential Decree in 1990. The ratification has inspired the birth of Article 28B paragraph (2) in the Indonesian constitutional amendment in 2000. It is then translated into Law No. 23 of 2002 on Child Protection.30

In the Concluding Observation, the Committee on the Rights of the Child urges Indonesia to amend its laws and raise the minimum age limit for girls to marry to 18 years, as well as to review the minimum age limit in different laws to conform with the principles and provisions in the CRC and to eliminate any circumstances or causes which may result in children under 18 being viewed as adults. 31

In addition, the Committee on the Rights of the Child also provides a note in the field of legislation for Indonesia if national legislation is not fully adhered to the CRC, and urges Indonesia to take the necessary measures, namely:

(a) Adjusting the provisions of its domestic law to CRC;

(b) Adapt legislation at the local level to conform to the provisions of the CRC, including through the establishment of a government institution tasked with 
monitoring the establishment of local lawrelated products. 32

Article 6 of Law No. 12 of 2011 has been stipulated that the content of legislation should reflect the "principle of humanity". It does not explicitly mention the principle of nondiscrimination, but according to the elucidation of Article 6, the term "principle of humanity" means that any material on the content of legislation should reflect the protection and respect of human rights and the dignity of every citizen and resident Indonesia proportionally.

B. Prohibition of Discrimination on Children in National Law

Article 28B paragraph (2) of the 1945 Constitution of the Republic of Indonesia guarantees that "Every child shall have the right to survive, to grow and to develop and to be entitled to protection from violence and discrimination." The stipulation of the principle of non-discrimination in the 1945 Constitution of the Republic of Indonesia makes all the provisions in the laws and regulations in Indonesia should not be contrary to its provisions.

Article 1 point 5 of Law no. 39 of 1999 on Human Rights provides the definition of a Child as every 18-year-old and unmarried, including a child still in the womb if it is in child's best interest. Article 1 point 3 of the Human Rights Law provides that "Discrimination refers to any restriction, harassment, or exemption which is directly or indirectly based on the differentiation of people on the basis of religion, ethnicity, race, ethnicity, group, class, social status, economic status, gender, language, political beliefs, resulting in the reduction, deviation or abolition, recognition, implementation or use of human rights and fundamental freedoms in individual and collective life in the political, economic, legal, social, cultural and other aspects of life ". The Human Rights Law also regulates in particular the rights that children have with both other vulnerable groups in Article 41 paragraph (2) and individually in Articles 51 to 66.
Unfortunately, among the rights guaranteed to the child, no provision explicitly or explicitly guarantees the right of the child to avoid any form of discrimination. In Article 17 only stipulates that "Everyone, without discrimination, is entitled to obtain justice by filing petitions, filings and lawsuits, whether in criminal, civil, or administrative cases and on trial through a free and impartial judiciary process, a procedural law that guarantees an objective examination by an honest and fair judge to obtain a fair and right decision."

Article 1 point 2 of Law No. 4 of 1979 on the Child Welfare stated that "Children are someone who has not reached the age of 21 years and has never married". Unfortunately this law does not include the terms discrimination and regulate it. As the implementation of the ratification of the CRC, Indonesia has passed Law No. 23 of 2002 on Child Protection which explicitly regulates the principle of non-discrimination. In 2014, the Law is amended by Law No. 35 of 2014 on Amendment to Law No. 23 of 2002 on Child Protection which reinforces the need for sanctioning of penalties and fines for the perpetrators of crimes against the Child.33 In one of its considerations, the Law on Amendment to the Child Protection Law states that every child has the right to survival, growth and development and is entitled to protection from violence and discrimination as mandated in the 1945 Constitution of the Republic of Indonesia. It is expressly stated in the Law about the principle of non-discrimination, inter alia in Article 1 point 2, Article 13 sub-section

(1). In this Law, there are no grounds for avoiding discrimination. However, in the elucidation of Article 13 it is explained that the treatment of discrimination, such as the discriminatory treatment of ethnicity, religion, race, class, sex, ethnicity, culture and language, legal status of children, birth order of children, and physical and/or mental conditions.

Article 2 of Law No. 11 of 2012 on the Juvenile Court System states that one of the principles 
used in the Juvenile Court System is nondiscrimination. The elucidation of that article explaines the term of "non-discrimination" is the absence of different treatment based on tribe, religion, race, class, gender, ethnic, culture and language, Child's legal status, Child birth order, as well as physical and/or mental conditions.

Indonesia also has a special law on the elimination of discrimination. Unfortunately, the law only deals specifically with racial and ethnic discrimination, namely the Law No. 40 of 2008 on the Elimination of Racial and Ethnic Discrimination.

In the health sector there is Law No. 36 of 2009 on Health. The Health Law does not provide a definition of the term "discrimination" or provides reasons or grounds to avoid in order to avoid discrimination, but Article 133 provides that:

(1) Every infant and child is entitled to be protected and be avoided from any form of discrimination and violence that may harm their health.

(2) Governments, local governments and communities are obliged to ensure the protection of infants and children as referred to in paragraph

(1) and to provide health services as required.

Similar to the Health Law, Law No. 20 of 2003 on the National Education System also does not define the term "discrimination" or provide reasons or grounds to avoid in order for the child not to experience discrimination in accessing the right to education. In Article 11, it is only stipulated that the Government and the Local Government shall provide services and facilities, as well as ensure the implementation of quality education for every citizen without discrimination.

From the description above, it is apparent that in the 1945 Indonesian Constitution there is a provision on the prohibition of discrimination against children. However, it does not contain the reasons or grounds that should be avoided so that children do not experience discrimination in accessing their rights. Furthermore, there is no harmony in some laws relating to the protection of human rights or the protection of children in providing definition of the child. In addition, not all laws include non-discriminatory or basic principles that should be avoided so that children do not experience discrimination in accessing their rights as recommended by the Committee on the Rights of the Child.34

\section{Discriminative Law for Children}

States have the possibility of discriminating children through public policy formulated into legal products and public budgets. In some cases, there is distinctions, exceptions, restrictions or preferences based on multiple presuppositions of reasons such as race, color, sex, language, religion, political or other opinion, national or social origin, possession, birth or other status (Direct Discrimination), there are also some situations that indicate the distinction, exclusion, limitation or preference of some kind of discrimination but not based on forbidden reasons such as in the case of discrimination. Thus, such distinctions are often justified. The situation may be categorized as Indirect Discrimination.35

\section{Direct Discrimination}

The issue of discrimination against children appears in the Concluding observations provided by the Committee on the Rights of the Child on the periodic report submitted by Indonesia with regard to the minimum age difference for marriage between boys (19 years old) and girls (16 years old). In the Initial Reports submitted by Indonesia to the Committee on the Rights of the Child in 1993, it was stated that based on the Child Welfare Law which defines a child as a person who has not reached the age of 21 years old and has never married, then the age of 19 years old for boys and 16 years old for girls specified in the Marriage Law is recognized as the age of the children. However, the difference in the stipulation of these provisions is based on 
biological, cultural and cultural conditions, especially in rural areas where the majority of the population live as farmers and marry at a very young age. 36

The Committee on the Rights of the Child states that the provisions of the Marriage Law relating to the minimum age to marry may not be in accordance with the provisions on the prohibition of discrimination in the CRC as reflected in Article 2.37 The Committee on the Rights of the Child added that the best interests of the child and non-discrimination principles should be included in national law and a judicial mechanism must be provided to demand the existence of that principle in the law.38

In the Concluding Observations for the Second Periodic Report submitted by Indonesia, the Committee on the Rights of the Child expressed its concern that Indonesia has not revised the Marriage Law regulating the minimum age for marriage. The Committee on the Rights of the Child advises Indonesia to review the age-related provisions concerning children in different laws and regulations to conform with the principles and provisions of the Convention.

Unfortunately, until the third and fourth Periodic Reports submitted by Indonesia, the provisions of the discriminatory Marriage Law are still valid. In Concluding Observations, the Committee on the Rights of the Child still recommends some things that are not much different from the previous recommendation that is to revise the different minimum age limit provisions between girls and boys in accordance with the principles and provisions of the CRC.39

\section{Indirect Discrimination}

Article 2 of the CRC not only prohibits direct discrimination, but also indirect discrimination, which is a distinction which uses seemingly harmless reasons to distinguish the same situation but in fact the distinction effectively discriminates against persons on suspicion of reason. For example, a disabled child may be indirectly discriminated by a rule requiring a written test as an enrollment requirement. Formally, the basis of this discrimination is acceptable in the educational context. However, from the perspective of the disabled child, it may be an insurmountable obstacle in accessing educational rights. 40

The National Education System Law regulates community participation in education and community-based education. In practice, the arrangement led to schools that promote and promise better quality and certainly at a more expensive cost, especially when compared with the education held by the Government.41 The result is the quality of education, especially basic education received by children unevenly. Children with parents who can afford to pay higher school fees, have more school options, especially better schools. On the other hand, there are some schools that are impressed with receiving exiles because the school is receiving students from poor families and this kind of school is usually a school of inclusion - schools that accept students with disabilities.42 In this case through the National Education System Law, there has been indirect discrimination against children of poor families and children with disabilities to enjoy the right to equal education as guaranteed by the CRC and the 1945 Indonesian Constitution.

In addition, the National Education System Law also does not provide a guarantee for girls who engage in marriage, conceive or have children in order to retain their right to continue their education. This resulted in children or adolescent girls who had married, became pregnant will have difficulty in continuing their education because most often the school made policy to remove the students. 43 This makes them discriminated on the basis of sex. This issue has been the concern of the Committee on the Rights of the Child in the Concluding Observations of the Indonesian Reports in particular on the implementation of the obligations of Indonesia in ensuring the right of the child especially the right to education. 44 


\section{CONCLUDING REMARKS}

The existence of the CRC is to ensure that childen are born with inherent rights and should not be discriminated against because they are children. As one of the general principles in the CRC, non-discrimination principle imposes State Parties to prohibit any form of discrimination and to take positive action to promote their right to be free from discrimination. However, the non-discrimination principle does not bar affirmative action. It should be emphasized that the application of the nondiscrimination principle of equal access to rights does not mean identical treatment. States will often have to take affirmative action on behalf of disadvantaged and vulnerable groups of children to diminish or eliminate conditions that cause or help to perpetuate discrimination. In practice, the protection of children of all forms of rights apply to all children without exception. It is the State's obligation to protect children from discrimination entails various state's actions, including monitoring the implementation and reviewing the national law to ensure that all legislation, policy and practice is compatible with the non-discrimination principle contained in the CRC.

Article 2 of the CRC not only prohibits cases of direct discrimination, but also indirect discrimination. Unfortunately, both direct and indirect discriminaton occurs in the implementation of the Indonesian national law, particularly legislation concerning children, e.g Law No. 1 of 1974 on Marriage and Law No. 20 of 2003 on

National Education System. Additionally, discrimination cases against children in Indonesia also exist when there is no law provides about the concerning matters. Regarding these matters, according to the Article 2 of the CRC, Indonesia as a State Party has the obligation to review existing laws or enact new legislation with a view to implementing fully the article, and in particular to expressly prohibiting discrimination.

\section{REFERENCES}

[1] Camilla Ida Ravnbøl, "Intersectional Discrimination against Children: Discrimination against Romani children and anti-discrimination measures to address child traffickingee, Innocenti Working Paper No. IDP 2009-11, Florence: UNICEF Innocenti Research Centre, 2009.

[2] Frances Sheahan, Translating the Right to Non-Discrimination into Reality, Sweden: Save the Children, 2008.

[3] Javaid Rehman, International Human Rights Law: A

[4] Practical Approach, England: Pearson Education Limited, 2003.

[5] Samantha Besson, The Principle of NonDiscrimination in the Convention on the Rights of the Child, The International Journal of Children s Rights. 13: 433-461, 2005.

[6] UNICEF, Handbook on the Optional protocol on the Sale of Children, Child Prostitution and Child Pornography, Florence: UNICEF IRC, 2009.

[7] UNICEF, The State of the World's Children: Special

[8] Edition, New York: UNICEF, 2009.

[9] UNICEF, Child Marriage and The Law: Legislative

[10] Reform Initiative Series, New York: UNICEF, 2008.

[11] UNICEF, Implementation Handbook for the Convention on the Rights of the Child, New York: UNICEF, 2007.

\section{INTERNET}

[12] Ahmad Mukafi Niam,"Soal

Kecenderungan Komersialisasi Sekolah Berlabel Islam", 13 August 2017, (Available 
http://www.nu.or.id/post/read/80368/soal

kecenderungan-komersialisasi-sekolah-

berlabel islam-, [Accessed 20 Oktober 2017]).

[13] Anonim, "Dugaan Siswi Hamil Dikeluarkan sekolah Tuai Polemik", 23 februari 2016 , (Availableat:http://www.borneonews.co.id /berita/29010-dugaan-siswi-hamildikeluarkan-sekolah-tuai-polemik, [Accessed 20 October 2017]).

[14] Child Rights International Network (CRIN), Discrimination and the CRC, (Available at: https://www.crin.org/en/guides/introducti on/discri mination-and-crc, [Accessed 8 April 2017]).

[15] CPPS UGM, Pelajar Perempuan Hamil Kerap Dikeluarkan dari Sekolah, Mengapa?, 24 October 2017, (Available at: $\quad$ http://cpps.ugm.ac.id/pelajarperempuan hamil-kerap-dikeluarkan-darisekolah-mengapa/, [Accessed 25 October 2017]).

[16] Iradhatie Wurinanda, "Biaya Sekolah Mahal, Orang Tua tak Punya Pilihan”, 21 June 2016 (Available at: https://news.okezone.com/read/2016/06/2 1/65/1421 419/biaya-sekolah-mahalorangtua-tak-punya-pilihan , [Accessed 20 October 2017]).

[17] Kertaning Tyas, "Sekolah Inklusi Bukan Sekolah Buangan", 27 November 2016, (Available at:

https://www.kompasiana.com/javanology/ sekolah-inklusi-bukan-sekolah-

buangan_583af5c3757a61c215285bd0, [diakses tanggal 20 October 2017]).

[18] Office of the United Nations High Commissioner for Human Rights, The United Nations human rights treaty system: an introduction to the core human rights treaties and the treaty bodies, Fact

\section{Sheet No.}

30, p. 18. (Available at: http://www.ohchr.org/Documents/Publicat
ions/Fact Sheet30Rev1.pdf, [Accessed 10 April 2017]).

[19] Sarwo Edy, "Sekolah Inklusi bukanlah sekolah Buangan", 20 October 2015, (Available at: https://www.kompasiana.com/sarwoedy/s ek lah-inklusi-bukanlah-sekolahbuangan_5625931ac022bd7112f3f30a, [Accessed 20 October 2017]).

[20] Tulus Adarma, "Disdik: Minat Warga di Sekolah Negeri Mulai Menurun", 27 September 2017, (Available at: http://beritajatim.com/pendidikan_kesehat an/309314/disdik:_minat_warga_di_sekol ah_negeri_mulai_ menurun.html, [Accessed 20 October 2017]).

[21] UNICEF, Covention on the Rights of the Child: Frequently Asked Question, (Available at: https://www.unicef.org/crc/index_30229.h tm, [Accessed 10 April 2017])

\section{STATE REPORTS DAN CONCLUDING OBSERVATIONS}

[22] Committee on the Rights of the Child, Concluding Observation CRC/C/15/Add.223, 26 February 2004.

[23] Committee on the Rights of the Child, Concluding Observations, CRC/C/15/Add.7, 18 October 1993.

[24] Commiittee on the Rights of the Child, Concluding Observations, CRC/C/15/Add.25, 24 October 1994.

[25] Commiittee on the Rights of the Child, Concluding Observations, CRC/C/IDN/CO/3-4, 10 July 2014.

[26] Commiittee on the Rights of the Child, Concluding Observations on the Combined 3rd and 4th Periodic Report of indonesia, CRC/C/IDN/CO/3-4, 10 July 2014.

[27] Indonesia, CRC/C/3/Add.10, 14 January 1993.

[28] Indonesia, CRC/C/IDN/3-4, 31 October 2012. 


\section{GENERAL COMMENTS}

[29] Committe on the Rights of the Child, General Comment No. 1, "The Aims of Education", CRC/GC/2001/1.

[30] Committee on the Rights of the Child, General Comment No. 5, 2003, CRC/GC/2003/5.

[31] Committee on the Rights of the Child, General Comment No. 5, 2003, CRC/GC/2003/5.

[32] Committee on the Rights of the Child, General Comment No. 7, 2005, CRC/C/GC/7/Rev.1.

[33] Human Rights Committee, General Comment No.18, 1989, HRI/GEN/1/ Rev.8.

[34] Human Rights Committee, CCPR General Comment No.18, 1993, CCPR/C/21/Rev.1/Add.4 